\title{
Identifikasi dan Evaluasi Risiko Manajemen Rantai Pasok Komoditas Jagung dengan Pendekatan Logika Fuzzy
}

\author{
Suharjito \\ Pusat Teknologi Agroindustri, BPPT, Jakarta \\ Teknologi Industri Pertanian, Fakultas Teknologi Pertanian IPB \\ harjito@yahoo.com \\ Marimin \\ Teknologi Industri Pertanian, Fakultas Teknologi Pertanian IPB \\ Machfud \\ Teknologi Industri Pertanian, Fakultas Teknologi Pertanian IPB \\ Bambang Haryanto \\ Pusat Teknologi Agroindustri, BPPT, Jakarta \\ Sukardi \\ Teknologi Industri Pertanian, Fakultas Teknologi Pertanian IPB
}

\begin{abstract}
To meet the needs of the national corn on the feed industry that requires a continuous supply of raw materials with a definite quantity throughout the year, in the national maize production conditions that is not continuous and fluctuating, it is necessary supply planning and storage methods to avoid the risk of maize corn supply crisis form of food shortages or rising feed prices. One method is to apply the concept of supply chain risk management. The high level of dependence and complexity of networks makes supply chain of agricultural products supply chain is becoming more vulnerable to interference. The risk of supply chain disturbance can occur internally (the relation between the organization with a network of suppliers) and external (between network suppliers with the environment). Therefore it is necessary to identify and evaluate supply chain risks in order to avoid continuing problems that can occur at any point in the supply chain network. The objective of this study is to describe the model of identification and evaluation for maize supply chain risk. This model can be used to identify the dominant risk factors and variables at each level of supply chain so that it will be obtained appropriate recommendations action to anticipate them. Risk identification will be conducted with fuzzy AHP approach and risk evaluation would be done by using fuzzy logic with data input form the opinion of several experts maize supply chain.
\end{abstract}

Keywords: Evaluation and Risk Identification, Corn Supply Chain, Fuzzy Logic. 


\section{Pendahuluan}

Sejumlah permasalahan yang menyebabkan melemahnya ketahanan pangan saat ini dapat diidentifikasi, yaitu konversi lahan pertanian, menurunnya produktifitas pertanian, sarana dan prasarana pertanian yang tidak memadai, lemahnya kelembagaan (regulasi dan infrastruktur), serta sistem pemasaran dan rantai pasokan yang tidak terkendali. Khusus pada sebab permasalahan terakhir, adanya kesenjangan informasi antara konsumen dan produsen menyebabkan terjadinya distorsi pada aspek distribusi dan aksesibilitas ketahanan pangan. Distorsi ini memunculkan sejumlah persoalan tidak lancarnya pasokan bahan pangan, tidak proporsionalnya pembagian risiko, nilai tambah dan keuntungan antar pelaku, rendahnya mutu dan keamanan produk pangan, tidak efisiennya biaya sepanjang rantai pasokan serta melonjaknya harga produk pangan. Petani, sebagai penyedia bahan baku adalah pelaku utama yang menderita kerugian dalam distorsi tersebut, yaitu menanggung porsi risiko yang lebih besar dan menerima porsi keuntungan dan nilai tambah yang lebih kecil (Arifin, dkk. 2001).

Risiko didefinisikan sebagai hasil dari kejadian yang berpengaruh negatif yang mempunyai kemungkinan terjadi dan menghasilkan sejumlah kerusakan (March and Shapira 1987). Sedangkan dalam kamus besar bahasa Indonesia, risiko adalah kemungkinan terjadinya peristiwa yang dapat merugikan perusahaan. Risiko rantai pasok dapat didefinisikan sebagai: kerusakan yang mempunyai kemungkinan terjadi yang disebabkan oleh suatu kejadian dalam sebuah perusahaan pada rantai pasok atau lingkungannya sehingga menimbulkan pengaruh negatif terhadap proses bisnis pada lebih dari satu perusahaan dalam rantai pasok (Kersten, Hohrath, and Böger 2007). Peningkatan tingkat kebergantungan dan kompleksitas dari jaringan rantai pasok saat ini menjadikan rantai pasok secara keseluruhan menjadi lebih rentan terhadap gangguan. Setiap gangguan yang terjadi dalam salah satu pelaku rantai pasok dapat mempengaruhi jaringan rantai pasok secara keseluruhan seperti berhentinya arus informasi dan sumber daya dari hulu ke hilir dalam rantai pasok yang menyebabkan ketidakseimbangan antara pasokan dan permintaan.

Dua metode utama untuk mengevaluasi risiko rantai pasok adalah metode evaluasi risiko berdasarkan pendapat pakar dan metode evaluasi risiko secara statistik (Klimov and Merkuryev 2006). Metode evaluasi risiko berdasarkan pendapat pakar biasanya disebut sebagai model evaluasi risiko kualitatif dan metode evaluasi secara deterministik dan statistik disebut sebagai model evaluasi risiko kuantitatif. Beberapa model evaluasi risiko kualitatif yang telah dilakukan adalah Santoso (2005), Wu et al. (2006) dan Schoenherr et al. (2008). Sedangkan beberapa model kuantitatif manajemen risiko rantai pasok telah juga dikembangkan oleh Nagurney et al. (2005), Xiaohui et al. (2006), Li and Hong (2007), Neureuther and Kenyon (2008) dan Lee (2008). Selain itu telah dikembangkan juga model gabungan antara evaluasi risiko kualitatif dan kuantitatif seperti yang dilakukan oleh Arisoy (2007) dan Wu dan Olson (2008).

Manajemen risiko rantai pasok produk pertanian berbeda dengan manajemen risiko rantai pasok produk manufaktur, karena (1) produk pertanian bersifat mudah rusak, (2) proses penanaman, pertumbuhan dan pemanenan tergantung pada iklim dan musim, (3) hasil panen memiliki bentuk dan ukuran bervariasi, (4) produk pertanian bersifat kamba, sehingga produk pertanian sulit untuk ditangani (Austin 
1992; Brown 1994). Manajemen risiko rantai pasok produk pertanian menjadi lebih sulit, karena beberapa sumber ketidakpastian dan hubungan yang kompleks antara pelaku dalam rantai pasok tersebut.

Sebagai produk pertanian, komoditas jagung tidak terlepas dari sifat-sifat tersebut, yaitu musiman karena pola tanam jagung tidak merata sepanjang tahun, sehingga kemungkinan terjadinya fluktuasi harga sangat tinggi. Berdasarkan data perkembangan harga jagung, pada bulan September-November merupakan puncak harga jual tertinggi. Pada bulan September-Desember, kebutuhan (konsumsi) lebih besar dibandingkan produksi, yang menyebabkan harga jagung naik. Periode tersebut merupakan puncak paceklik, sehingga harga jagung tinggi. Dalam periode Januari-April, produksi lebih tinggi dari kebutuhan, sehingga terjadi kelebihan produksi, yang menyebabkan harga jagung cenderung rendah (Zubachtirodin dkk. 2007). Di samping itu petani umumnya menjual hasil jagung hanya ke pedagang pengumpul atau ke pasar (pedagang penyalur kota atau pengecer di pasar umum). Dengan demikian, harga yang diterima petani relatif rendah dan fluktuatif. Keadaan ini kurang menguntungkan bagi petani, sebab tidak adanya jaminan harga yang layak. (Sarasutha dkk. 2007). Beberapa permasalahan jagung nasional adalah produktivitas rendah, yakni rata-rata 5 ton/ha dan mutu rendah. Kontinuitas produksi belum terjamin, kepastian pasar, dan harga belum ada. Modal investasi dan modal kerja terbatas. Petani belum bersahabat dengan lembaga keuangan formal karena kelompok tani dan gapoktan belum berfungsi optimal. Dari sisi pabrikan, masalahnya adalah pasokan bahan baku belum terjamin, sehingga pabrik beroperasi di bawah kapasitas optimal dan harus impor bahan baku jagung. Masalah lain, koordinasi pabrik dengan petani masih lemah, belum ada kerjasama pabrik dengan kelompok tani dan gapoktan, struktur pasar tidak bersaing sempurna, sehingga biaya transaksi tinggi. Oleh karena itu kajian ini bertujuan untuk mengidentifikasi risiko pada setiap tingkatan rantai pasok, pengukuran risiko rantai pasok, dan mitigasi risiko rantai pasok untuk mendukung tindakan pengambilan keputusan yang tepat dalam manajemen rantai pasok yang efektif, efisien dan responsif pada setiap tingkatan rantai pasok komoditas jagung. Sehingga akan tercipta kestabilan pasokan produk pangan dan non-pangan untuk meningkatkan kemandirian pangan nasional serta dapat mengantisipasi terjadinya krisis kerawanan pangan. Penelitian ini bertujuan untuk merumuskan suatu model identifikasi dan evaluasi risiko rantai pasok komoditas jagung pada setiap tingkatan jaringan rantai pasok.

\section{Metodologi Penelitian}

\section{II.1. Kerangka Pemikiran}

Kajian ini dilandasi dengan kerangka pikir pembuatan model identifikasi dan evaluasi risiko rantai pasok komoditas jagung. Untuk membuat model tersebut pertama-tama dibuat model struktur hierarki untuk menentukan faktor-faktor risiko dominan pada setiap tingkatan rantai pasok. Untuk mendapatkan faktor risiko tersebut dilakukan studi literatur dan konsultasi pakar di bidang manajemen risiko rantai pasok produk/komoditas jagung. Hasil dari identifikasi faktor risiko diidentifikasi lebih lanjut pada peubah risiko yang dapat menjadi sumber risiko pada setiap tingkatan rantai pasok. Setelah dapat mengidentifikasi faktor dan peubah risiko, maka dapat dilakukan evaluasi risiko dengan mengukur tingkat kejadian, 
paparan dan dampak dari setiap peubah risiko dengan nilai-nilai linguistik fuzzy. Nilai-nilai lingistik tersebut diagregasi dengan menggunakan metode rataan geometrik untuk mendapatkan nilai risiko setiap faktor dan setiap tingkatan, serta risiko rantai pasok global. Dengan diperolehnya risiko tersebut, maka dapat direkomendasikan tindakan untuk mengantisipasi agar diperoleh suatu rantai pasok komoditas jagung berkelanjutan.

\section{II.2. Model Identifikasi Risiko Rantai Pasok}

Model identifikasi risiko rantai pasok bertujuan untuk mengidentifikasi dan menentukan peubah-peubah dari setiap faktor risiko yang sangat berpengaruh terhadap setiap risiko tingkatan rantai pasok. Dengan model ini diperoleh faktorfaktor risiko pada setiap tingkatan rantai pasok beserta dengan peubah-peubah risikonya sehingga setiap tingkatan rantai pasok akan terfokus pada beberapa faktor risiko terpilih tersebut dalam melakukan manajemen risiko rantai pasok. Input model adalah struktur hierarki identifikasi risiko rantai pasok, yang meliputi tujuan manajemen risiko rantai pasok, pelaku dan tingkatan rantai pasok, faktor risiko rantai pasok dan peubah risiko rantai pasok. Kemudian dari struktur hierarki ini dinilai oleh beberapa ahli (akademisi, peneliti dan praktisi rantai pasok komoditas jagung) rantai pasok, sehingga terpilih beberapa faktor utama (dominan) dari setiap tingkatan rantai pasok. Hasil penilaian pakar dimasukan ke dalam basis data identifikasi risiko dengan mengambil empat faktor dengan bobot tertinggi dari hasil pembobotan. Di samping itu input model ini adalah hasil penilaian tingkat kemungkinan, tingkat dampak dan tingkat paparan dari setiap peubah risiko untuk dapat diagregasi, sehingga diperoleh tingkat risiko setiap faktor.

Model ini menggunakan motode fuzzy AHP (Analytical Hierarchy Process) yang digunakan oleh Nepal et al. (2010) untuk menentukan bobot dari setiap faktor risiko dan pemilihan faktor risiko dengan bobot tertinggi dengan input penilaian ahli. Output dari model adalah diperolehnya faktor-faktor risiko yang sangat berpengaruh dalam setiap tingkatan rantai pasok dan peubah-peubah risiko dari setiap faktor tersebut yang kemudian dimasukan ke dalam basis data. Di samping itu, model ini juga akan menghasilkan bobot peubah dan bobot faktor risiko serta bobot tingkatan rantai pasok yang akan disimpan dalam basis data bobot peubah, bobot faktor dan bobot tingkatan rantai pasok sebagai pembobot untuk menghitung nilai agregasi faktor risiko, nilai agregasi risiko tingkatan rantai pasok dan nilai agregasi risiko rantai pasok secara global. Pada umumnya pengembangan metode fuzzy AHP melalui beberapa tahapan, yaitu pembuatan struktur hierarki, penilaian alternatif dan kriteria, fuzzyfikasi terhadap hasil penilaian, defuzzifikasi nilai skor fuzzy, membuat matrik kriteria dan alternatif, menghitung bobot kriteria, menghitung nilai eigen setiap alternatif, menghitung consistency ratio, menghitung skor akhir, menentukan ranking dari skor akhir (Suharjito dan Marimin 2008). Adapun alur proses model identifikasi risiko dapat diperlihatkan dengan Gambar 1.

\section{II.3. Model Evaluasi Risiko Rantai Pasok}

Model evaluasi risiko rantai pasok digunakan untuk mengukur tingkat risiko setiap peubah risiko rantai pasok dengan input nilai fuzzy terhadap tingkat kemungkinan, dampak, dan paparan risiko. Model menggunakan metode Fuzzy FMEA (Failure Mode and Effect Analysis) yang dikembangkan oleh Yeh \& Hsieh 
(2007) untuk menentukan nilai peubah risiko dari setiap faktor yang sudah terpilih dari pembobotan pakar dengan input tingkat kemungkinan, tingkat dampak dan tingkat paparannya. Tingkat penilaian tersebut menggunakan nilai fuzzy dan direpresentasikan dengan metode TFN (Triangular Fuzzy Number) untuk setiap fungsi keanggotaannya. Sedangkan untuk menilai tingkat risiko peubah digunakan fuzzy inference system mamdani, dengan input peubah linguistik fuzzy posibilitas, dampak dan paparan serta outputnya adalah linguistik fuzzy FRPN (fuzzy risk priority number).

Linguistik fuzzy posibilitas mempunyai nilai TP (Tidak pernah) dengan jangkauan nilai 1-2, SJ (Sangat Jarang) dengan jangkauan nilai 1-3, J (jarang) dengan jangkauan nilai 2-5, KK (Kadang-kadang) dengan jangkauan nilai 4-7, S (Sering) dengan jangkuan nilai 6-9, SS (Sangat Sering) dengan jangkuan nilai 8-10 dan P (Pasti) dengan jangkuan nilai 9-10. Adapun representasi fungsi keanggotaan TFN (Triangular Fuzzy Number) dari tingkat posibilitas dapat dijelaskan dengan Gambar 2.

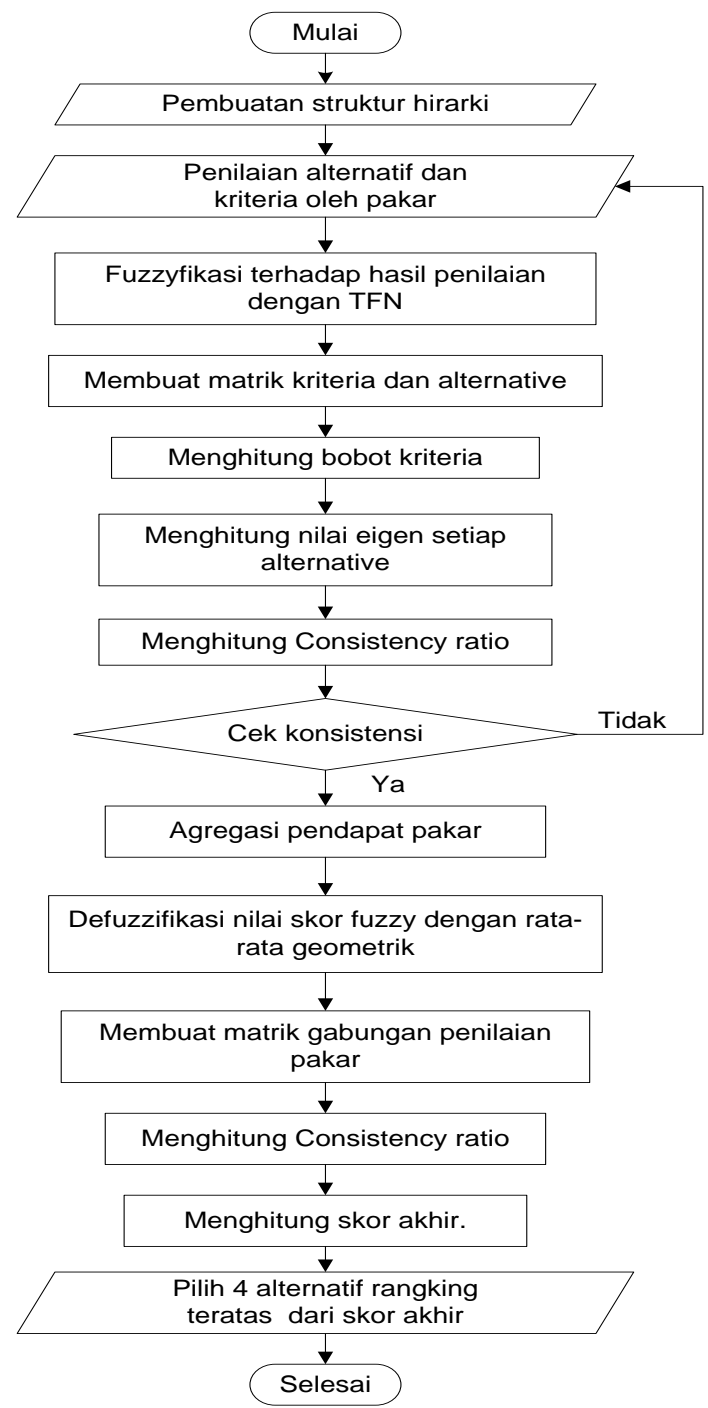

Gambar 1. Diagram alir identifikasi peubah dan faktor risiko rantai pasok 


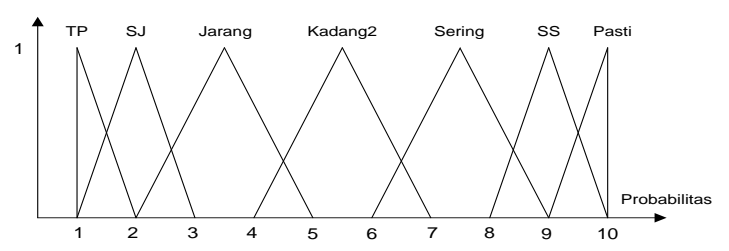

Gambar 2. Fungsi keanggotaan fuzzy posibilitas risiko

Dampak dan paparan risiko direpresentasikan dengan nilai linguistik fuzzy PR (Tidak Pernah) dengan jangkauan nilai 1-2, SR (Sangat Rendah) dengan jangkauan nilai 1-3, $R$ (Rendah) dengan jangkauan nilai $2-5$, S (Sedang) dengan jangkauan nilai 3-8, T (Tinggi) dengan jangkuan nilai 6-9, ST (Sangat Tinggi) dengan jangkuan nilai 810 dan PT (Paling Tinggi) dengan jangkuan nilai 9-10. Representasi fungsi keanggotaan TFN (Triangular Fuzzy Number) dari dampak risiko dapat dijelaskan dengan Gambar 3.

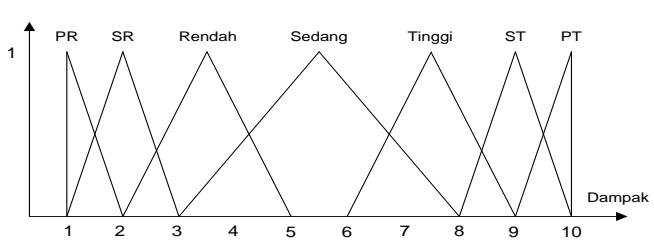

Gambar 3. Fungsi keanggotaan fuzzy dampak risiko

Output dari penilaian input dampak, posibilitas dan paparan akan direpresentasikan dengan nilai linguistik fuzzy TA (Tidak Ada risiko) dengan jangkauan 1-50, HTA (Hampir Tidak Ada risiko) dengan jangkuan 1-100, SR (Sangat rendah) dengan jangkauan nilai 100-250, $R$ (Rendah) dengan jangkauan nilai 150400, S (Sedang) dengan jangkuan nilai 250-550, HT (Hampir Tinggi) dengan jangkauan nilai 400-700, T (tinggi) dengan jangkauan nilai 550-900, ST (Sangat tinggi) dengan jangkauan nilai 700-100, dan PT (Paling Tinggi) dengan jangkauan nilai 9001000. Nilai jangkauan tersebut diperoleh dari nilai RPN (Risk Priority Number) yang merupakan hasil perkalian dari nilai posibilitas, nilai dampak dan nilai paparan dari peubah risiko. Fungsi keanggotaan fuzzy peubah risiko (FRPN) dapat direpresentasikan dengan Gambar 4.

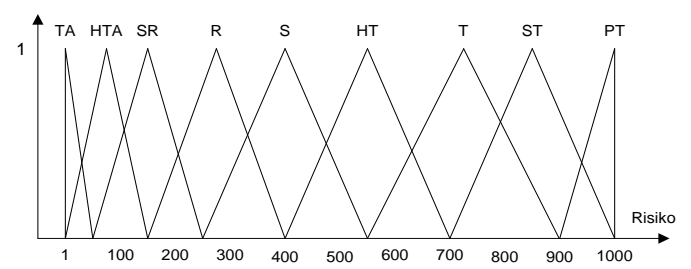

Gambar 4. Fungsi keanggotaan fuzzy output risiko (FRPN) 


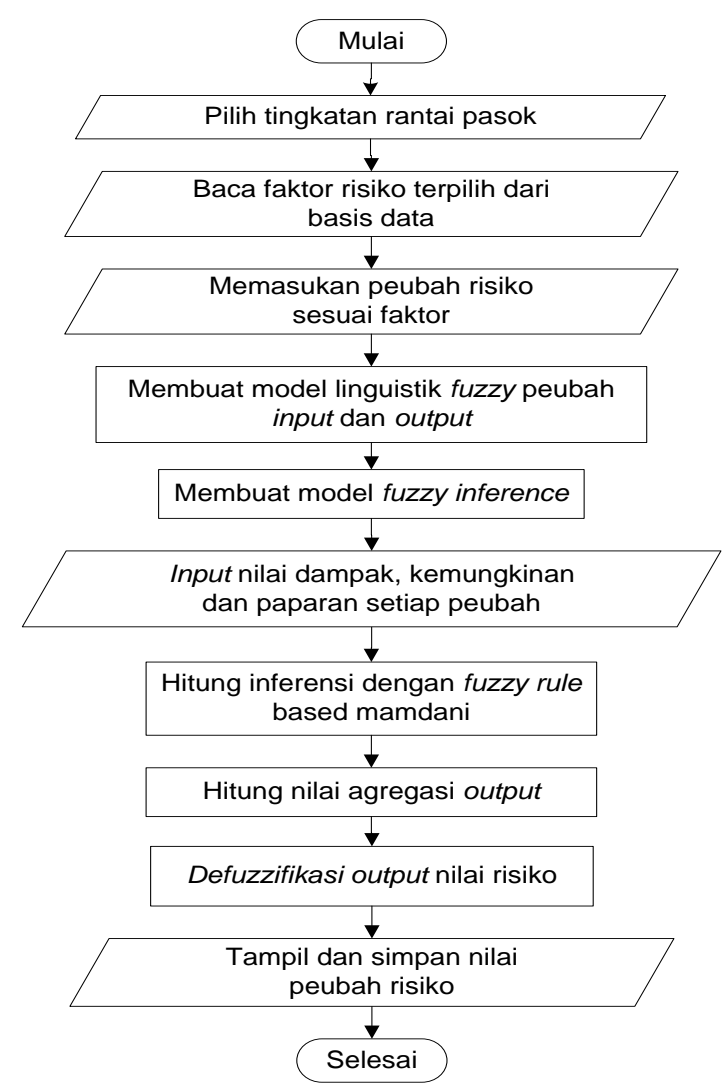

Gambar 5. Diagram alir model evaluasi risiko rantai pasok

Untuk menentukan nilai risiko (FRPN) digunakan fuzzy inference system dengan aturan fuzzy IF-THEN. Banyaknya aturan fuzzy IF-THEN adalah 343, karena menggunakan 3 input dan setiap inputnya mempunyai 7 nilai linguistik fuzzy.

Nilai agregasi output dari setiap pakar yang menilai peubah risiko dilakukan dengan menggunakan metode rataan geometrik. Demikian juga proses defuzzyfikasi dilakukan untuk mendapatkan nilai tunggal dari setiap peubah risiko dengan menggunakan metode rataan geometrik.

\section{II.4. Model Agregasi Risiko Rantai Pasok}

Model agregasi risiko rantai pasok terdiri dari tiga sub-model, yaitu sub-model agregasi faktor risiko, sub-model agregasi risiko tingkatan dan sub-model agregasi risiko total rantai pasok. Input dari model ini adalah nilai peubah risiko yang merupakan output dari model evaluasi risiko rantai pasok dan nilai bobot peubah input yang merupakan hasil output dari model identifikasi risiko rantai pasok. Output dari model ini adalah nilai agregasi peubah risiko untuk mendapatkan nilai setiap faktor risiko, nilai agregasi faktor risiko untuk mendapatkan nilai risiko setiap tingkatan dan nilai agregasi risiko tingkatan untuk mendapatkan nilai risiko total rantai pasok. Metode agregasi nilai faktor risiko menggunakan rataan pembobot peubah risiko dengan rumus berikut:

$$
\begin{aligned}
& \overline{B B}=\sum_{i=1}^{n} w_{i} B B_{i} \\
& \overline{B T}=\sum_{i=1}^{n} w_{i} B T_{i}
\end{aligned}
$$




$$
\overline{B A}=\sum_{i=1}^{n} w_{i} B A_{i}
$$

Nilai batas bawah $\left(\mathrm{BB}_{\mathrm{i}}\right)$, batas tengah $\left(\mathrm{BT}_{\mathrm{i}}\right)$ dan batas atas $\left(\mathrm{BA}_{\mathrm{i}}\right)$ dari nilai fuzzy masing-masing peubah risiko hasil inferensi untuk mendapatkan nilai batas bawah, batas tengah dan batas atas agregasi dari nilai faktor risiko. Sedangkan jumlah bobot peubah risiko mempunyai nilai sama dengan satu seperti persamaan di bawah.

$$
\sum_{i=1}^{n} w_{i}=1
$$

Menurut Marimin (2007), defuzzyfikasi merupakan suatu proses konversi output fuzzy ke output yang bernilai tunggal (crips), proses defuzzyfikasi dilakukan dengan metode rataan geometrik, dengan rumus, berikut:

$$
N_{\text {crips }}=\sqrt[3]{\overline{B B} * \overline{B T} * \overline{B A}}
$$

Setiap penilaian risiko tidak hanya dilakukan oleh seorang pelaku rantai pasok, maka perlu dilakukan agregasi hasil penilaian dari beberapa hasil penilian risiko sebelumnya, untuk mendapakan nilai tunggal hasil penilaian akhir. Proses agrgasi penilaian risiko setiap pakar/ahli yang menilai risiko dilakukan dengan metode rataan geometrik dengan menggunakan rumus berikut:

$$
\begin{aligned}
& B B_{i}=\sqrt[n]{\prod_{1}^{n} B B_{i n}} \\
& B T_{i}=\sqrt[n]{\prod_{1}^{n} B T_{i n}} \\
& B T_{i}=\sqrt[n]{\prod_{1}^{n} B A_{i n}}
\end{aligned}
$$

\section{Hasil Penelitian}

\section{III.1. Rantai Pasok Komoditas Jagung}

Rantai pasok dapat dipandang sebagai sebuah sistem yang mempunyai unsurunsur yang teratur, saling berkaitan dan mempunyai tujuan tertentu. Rantai pasok produk/komoditas jagung mempunyai unsur pelaku yang terlibat langsung dalam tingkatan rantai pasok, yaitu petani, pengumpul, agroindustri, distributor dan konsumen. Di samping itu terdapat juga unsur pelaku yang tidak terlibat langsung dalam rantai pasok, yaitu pemerintah, lembaga keuangan atau bank dan pemangku kepentingan lain sebagai lingkungan dari sistem. Setiap pelaku dalam rantai pasok tersebut mempunyai tujuan dan kepentingan masing-masing yang kadang-kadang bersifat konflik. Untuk mengatasi dan mengelola konflik kepentingan tersebut perlu adanya suatu sistem manajemen risiko, sehingga sistem rantai pasok dapat terkendali dalam usaha mencapai tujuan.

Jaringan rantai pasok produk/komoditi jagung terdiri dari producer (petani/gapoktan), collector (pedagang pengumpul tingkat Desa, Kecamatan, Kabupaten dan Propinsi), processor (industri pakan, industri makanan, dan industri lainya seperti etanol), retailer (pengecer besar dan kecil) dan konsumen (peternak unggas) sebagaimana terlihat pada Gambar 6. 
Dalam rantai pasok tersebut, risiko yang sering dihadapi petani/Gapoktan jagung adalah penggunaan varietas Jagung yang masih menggunakan varietas lokal dengan produktifitas rendah, penanganan pasca panen yang kurang baik sehingga menurunkan mutu dan jadwal tanam yang tidak tepat yang berdampak pada waktu panen raya harga jagung merosot tajam serta gagal panen karena lahan puso (Kasryno dkk. 2009).

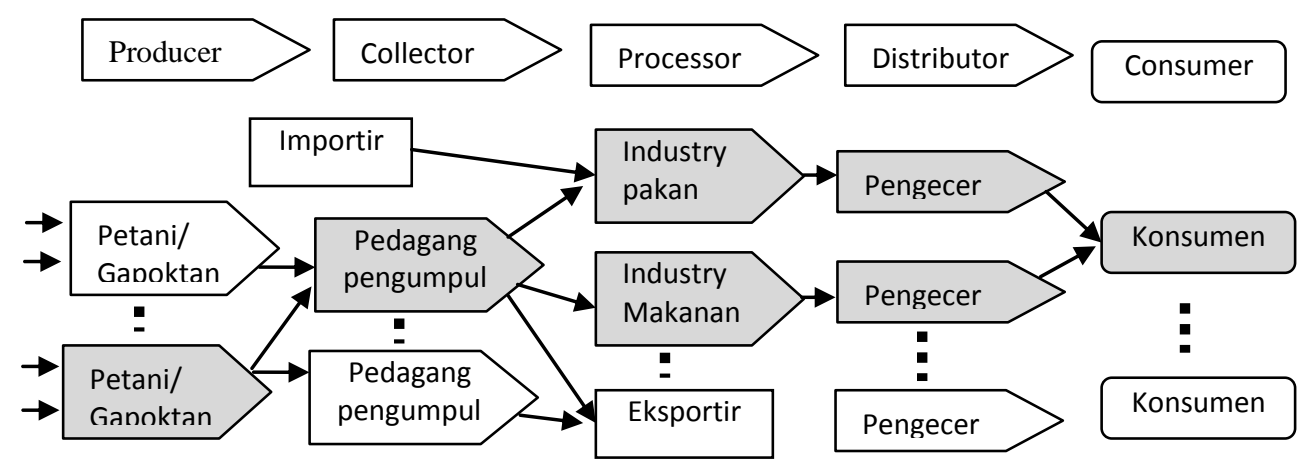

Gambar 6. Jaringan rantai pasok total produk/komoditas jagung

Risiko yang sering dihadapi oleh pedagang pengumpul atau kolektor adalah rendahnya mutu jagung, karena kebanyakan jagung dipanen pada musim hujan sehingga proses pengeringannya tidak sempurna dan menyebabkan tumbuhnya jamur. Di samping itu, risiko yang dihadapi adalah biaya penyimpanan dan pengeringan tambahan untuk mendapatkan mutu yang sesuai standar (Miskiyah dan Widaningrum 2008).

Dari sisi distributor risiko yang dihadapi terutama adalah risiko turunnya mutu jagung karena penyimpanan dan risiko karena pengangkutan di samping kendala transportasi dan distribusi ke pihak konsumen yaitu industri pakan dan industri pangan. Sedangkan risiko yang dihadapi pihak processor adalah ketidakpastian pasokan bahan baku sehingga kapasitas produksi tidak tercapai untuk mendapatkan efisiensi produksi tinggi. Di samping itu risiko yang dihadapi adalah ketidakpastian harga bahan baku.

\section{III.2. Struktur Hierarki Fuzzy AHP}

Berdasarkan hasil studi literatur (Hallikas et al. 2004; Agiwal and Mohtadi 2008) dan brainstorming serta interview mendalam dengan beberapa pakar (akademisi: seorang profesor manajemen rantai pasok, peneliti: balai pasca panen Bogor, praktisi: kepala divisi pengadaan bahan baku industri pakan PT. Charoen Pokphand Indonesia), maka diperoleh struktur hierarki dari fuzzy AHP identifikasi risiko rantai pasok komoditas jagung. Struktur hierarki yang diperoleh terdiri atas 3 level, yaitu:

1. Level1. Fokus/Goal: Identifikasi faktor risiko setiap tingkatan rantai pasok komoditas jagung. 
2. Level2. Tujuan manajemen risiko rantai pasok komoditas jagung yang menjadi perhatian dalam kajian ini adalah meningkatkan mutu pasokan (T1), menjamin kontinuitas pasokan yang stabil (T2), dan meningkatkan kesejahteraan petani (T3).

3. Level3. Aktor yang merupakan tingkatan rantai pasok komoditas jagung sesuai dengan Vorst (2006) terdiri atas tingkat petani (A1), tingkat pengepul (A2), tingkat agroindustri (A3), tingkat distributor (A4), dan tingkat konsumen (A5).

4. Level4. Alternatif faktor risiko yang teridentifikasi dari hasil interview mendalam dengan pakar dan hasil studi literatur adalah:

a. Risiko lingkungan yang diakibatkan oleh bencana alam, hama dan penyakit, kebijakan pemerintah, keamanan, kondisi sosial budaya dan politik, serta produk pesaing.

b. Risiko teknologi yang bersumber dari rendahnya penguasaan teknologi, perkembangan teknologi baru dan ketersediaan teknologi.

c. Risiko harga yang diakibatkan oleh adanya inflasi, nilai tukar dan bunga bank, rendahnya mutu produk dan jumlah pasokan.

d. Risiko pasokan yang bersumber dari keberagaman mutu pasokan, loyalitas pemasok dan ketersediaan pasokan.

e. Risiko transportasi yang diakibatkan oleh pemilihan moda transportasi, ketidakpastian waktu transportasi, keamanan di jalan dan kerusakan jalan mengurangi mutu produk.

f. Risiko pasar yang bersumber dari struktur pasar, fluktuasi harga, penolakan konsumen dan standarisasi mutu di pasar.

g. Risiko produksi yang diakibatkan oleh kapasitas, proses, dan penggunaan teknologi produksi serta mutu bahan baku.

h. Risiko informasi yang bersumber dari penggunaan metode peramalan, distorsi informasi dan penggunaan metode transfer informasi.

i. Risiko mutu yang diakibatkan oleh musim, metode transportasi, penyimpanan, variasi mutu pasokan dan proses produksi.

j. Risiko penyimpanan yang diakibatkan oleh ketidakpastian pasokan, ketidakpastian permintaan, penyusutan dan penurunan mutu serta lokasi geografis.

k. Risiko kemitraan yang bersumber dari pemilihan mitra, putusnya jaringan komunikasi, putusnya jaringan transportasi dan komitmen mitra.

Berdasarkan struktur hierarki pada Gambar 7 dilakukan perbandingan tingkat kepentingan dengan melibatkan beberapa pakar dalam bidang rantai pasok dan pasca panen komoditas jagung. Hasil penilaian pakar diagregasi untuk mendapatkan suatu nilai tunggal evaluasi risiko komoditas jagung.

Hasil pembobotan pakar diperoleh bahwa tujuan peningkatan mutu pasokan mempunyai bobot tertinggi, disusul dengan tujuan peningkatan kesejahteraan petani dan tujuan menjamin kontinuitas pasokan bahan baku komoditas jagung berturut turut dengan bobot nilai 0.406, 0,328 dan 0,265. Dari hasil tersebut dapat disimpulkan bahwa dalam manajemen risiko rantai pasok komoditas jagung mempunyai tujuan utama untuk meningkatkan mutu pasokan pada agroindustri, karena dengan peningkatan mutu tersebut dapat mengurangi terjadinya kerusakan produk dalam tahap penyimpanan dan peningkatan harga, sehingga dapat meningkatkan pendapatan petani. Di samping itu juga diperoleh nilai pembobotan 
risiko setiap tingkatan dalam rantai pasok komoditas jagung, sebagaimana dapat diperlihatkan dengan Gambar 8.

Dari Gambar 8 di atas terlihat bahwa risiko di tingkat petani mempunyai bobot nilai yang tertinggi dibandingkan dengan risiko di tingkat lain dalam jaringan rantai pasok. Hal ini dapat disimpulkan bahwa dalam rantai pasok komoditas jagung petani mempunyai kecenderungan menanggung risiko yang lebih tinggi dibandingkan dengan yang lain dalam jaringan rantai pasok komoditas jagung. Oleh karena itu, perlu dikaji lebih mendalam risiko apa saja yang harus dihadapi oleh petani sebagai penanggung risiko tertinggi sehingga dapat dilakukan tindakan yang tepat guna mengantisipasi risiko tersebut, baik secara sendiri maupun secara bersama dalam jaringan rantai pasok.

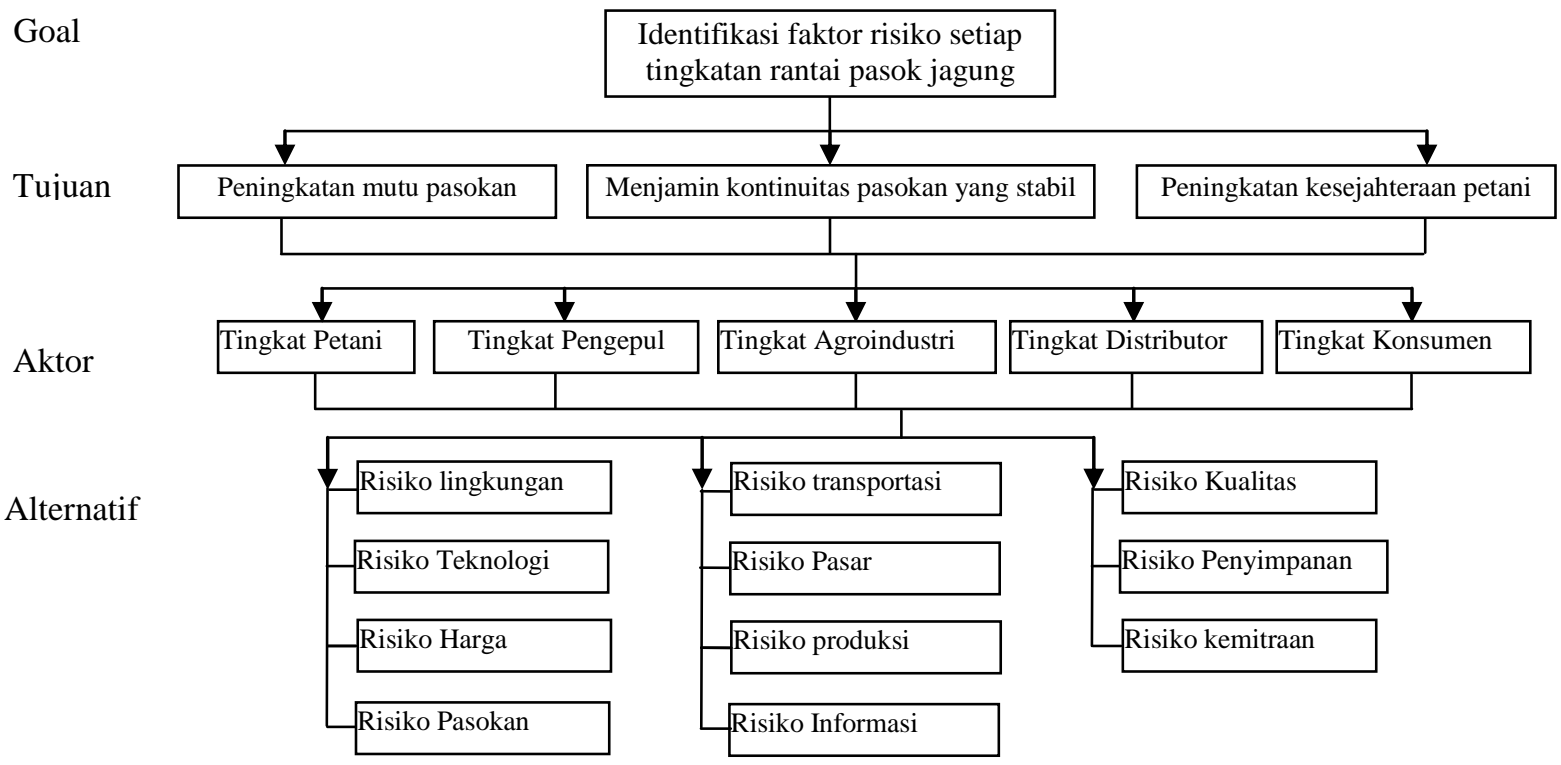

Gambar 7. Struktur hierarki fuzzy AHP identifikasi risiko rantai pasok

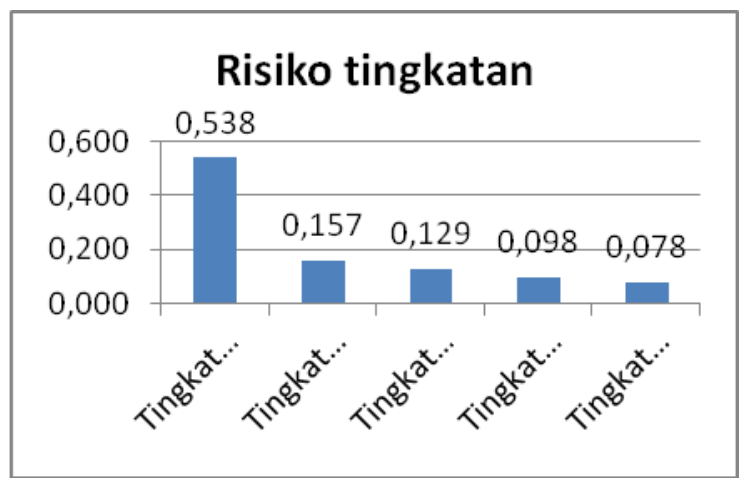

Gambar 8. Histogram perbandingan tingkat risiko pelaku rantai pasok komoditas jagung 


\section{III.3. Analisis risiko tingkat Petani}

Analisis risiko pada tingkat petani dilakukan untuk mengetahui faktor dan peubah risiko yang harus dihadapi oleh petani dalam manajemen rantai pasok guna meningkatkan mutu produk jagung. Hasil pembobotan faktor risiko dengan menggunakan fuzzy AHP diperoleh bahwa bobot faktor risiko tertinggi di tingkat petani adalah risiko mutu, disusul oleh risiko harga, risiko lingkungan, risiko pasokan dan risiko pasar. Distribusi hasil pembobotan faktor risiko tingkat petani tersebut dapat diperlihatkan dengan Gambar 9. Dari hasil tersebut terlihat bahwa empat faktor risiko dominan yang harus dihadapi oleh petani jagung adalah risiko mutu, risiko harga, risiko lingkungan dan risiko pasokan.

Untuk mengetahui lebih dalam sumber atau peubah risiko dari setiap risiko dominan tersebut maka perlu dilakukan kajian mendalam terhadap tingkat kejadian dan dampak dari setiap peubah risikonya. Risiko kualitas pada tingkat petani dipengaruhi oleh musim dan cuaca, proses pasca panen, penggunaan bibit, dan proses budidaya tanaman. Risiko harga di tingkat petani dipengaruhi oleh rendahnya mutu, jumlah pasokan pada musim panen raya, nilai tukar rupiah dan inflasi. Risiko lingkungan di tingkat petani dipengaruhi oleh beberapa peubah yaitu bencana alam, hama dan penyakit, kebijakan pemerintah, keamanan, kondisi sosial budaya dan politik. Sedangkan risiko pasokan di tingkat petani bersumber dari ketersediaan pupuk, ketersediaan lahan, akses informasi dan pemilihan jadwal tanam.

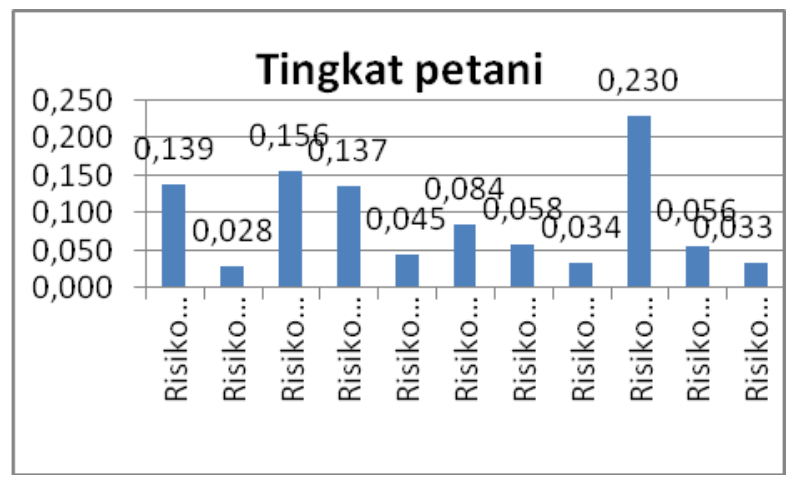

Gambar 9. Histogram perbandingan bobot faktor risiko di tingkat petani

Hasil evaluasi peubah risiko di tingkat petani berdasarkan faktor risiko dominan dapat diperlihatkan bahwa risiko utama yang dihadapi petani dalam rantai pasok komoditas jagung adalah risiko mutu karena proses pasca panen yang kuran baik dan karena musim atau cuaca, karena biasanya musim panen raya terjadi pada musim penghujan, sehingga petani sangat kesulitan dalam hal pengeringan untuk dapat memenuhi standar kualitas yang dipersyaratkan industri. Untuk mengatasi masalah ini, petani perlu diberikan pengetahuan dan pemahaman cukup baik dalam hal pasca panen, meliputi pemanenan seperti pemilihan waktu panen yang tepat, pengeringan dan pemipilan agar mendapatkan jagung pipil yang bermutu. Di samping itu risiko yang cukup krusial pada tingkat petani adalah risiko fluktuasi harga dan risiko kurangnya akses informasi pasar. Risiko ini terjadi akibat dari kebiasaan petani yang menanam jagung secara tradisional artinya tidak menggunakan jadwal tanam yang memperhatikan kebutuhan dan ketersediaan jagung pasar, sehingga harga jagung cenderung fluktuatif karena ketersediaannya yang tidak pasti dan tersedia melimpah 
pada saat panen raya. Untuk mengatasi hal tersebut dapat dilakukan dengan memilih jadwal tanam yang tepat dengan penggiliran jadwal tanam antar kelompok tani sehingga ketersedian jagung di pasar akan terkendali sesuai dengan permintaan pasar.

\section{III.4. Analisis risiko tingkat pengumpul}

Berdasarkan hasil identifikasi risiko pada tingkat pedagang pengumpul dengan menggunakan fuzzy AHP diperoleh empat faktor risiko utama yang dihadapi oleh pedagang pengumpul dalam rantai pasok komoditas jagung yaitu risiko harga, risiko pasokan, risiko mutu dan risiko pasar. Nilai lengkap dari hasil identifikasi risiko pada tingkat pedagang pengumpul dapat dilihat pada Gambar 10.

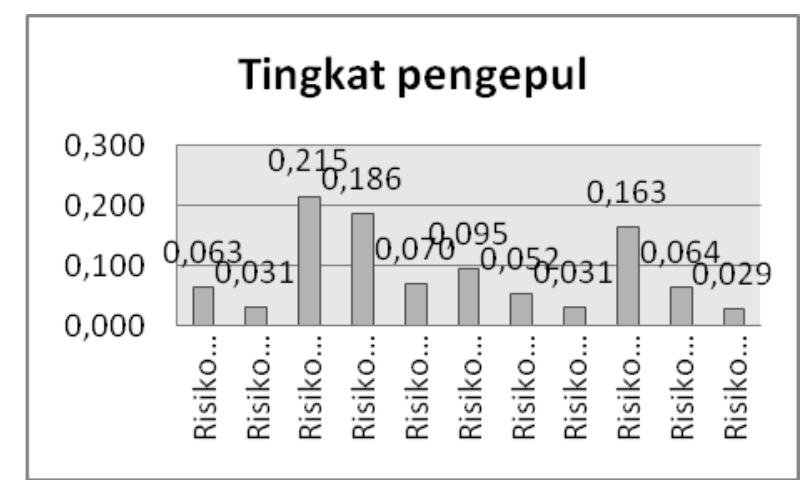

Gambar 10. Histogram perbandingan bobot faktor risiko di tingkat pedagang pengumpul

Hasil evaluasi risiko terhadap empat faktor risiko tersebut diperoleh bahwa risiko paling besar yang dihadapi oleh pedagang pengumpul adalah risiko keberagaman mutu pasokan. Untuk mengatasi risiko tersebut biasanya pedagang menggunakan metode pembelian dengan variasi harga sesuai mutu jagung dari petani. Namun cara ini sering merugikan pihak petani, karena kurangnya pengetahuan petani tentang mutu, sehingga petani sering dibohongi oleh pihak pengumpul dengan menyamaratakan berbagai mutu komoditas jagung dengan mutu yang rendah.

Untuk mengatasi risiko harga, pedagang pengumpul biasanya melakukan penyimpanan jagung pada saat panen raya kemudian menjualnya pada saat pasokan jagung sudah mulai menurun, sehingga akan mendapatkan margin keuntungan yang lebih tinggi, walaupun metode ini harus memperhitungkan nilai penyusutan dan biaya penyimpanannya.

\section{III.5. Analisis risiko tingkat agroindustri}

Dari hasil analisis risiko pada tingkat agroindustri diperoleh empat faktor risiko yang sering dihadapi tingkat agroindustri dalam rantai pasok komoditas jagung yaitu risiko mutu, risiko pasokan, risiko harga dan risiko lingkungan (Gambar 10).

Berdasarkan hasil evaluasi risiko terhadap empat faktor risiko tersebut diperoleh bahwa pengaruh utama risiko mutu adalah mutu pasokan bahan baku yang relatif rendah. Sedangkan risiko harga dipengaruhi oleh risiko fluktuasi harga bahan baku yang relatif tinggi. Kemudian risiko pasokan dipengaruhi oleh risiko keberagaman 
mutu pasokan yang menimbulkan permasalahan dalam penggudangan dan penyimpanan, karena produk yang rusak akan cenderung mengkontaminasi produk yang tidak rusak, jika ditampung pada tempat yang sama.

Untuk mengatasi risiko tersebut, dapat dilakukan dengan kontrak pembelian dengan pihak pengumpul dengan persyaratan mutu tertentu. Tetapi dalam kenyataan di lapangan tidak dapat dilakukan, karena komitmen mitra dalam kontrak tersebut relatif rendah, sehingga proses pengadaan bahan baku yang dilakukan pihak agroindustri adalah pembelian dengan persyaratan kualitas tertentu pada pihak pedagang dan akan menolak, jika pasokan tidak sesuai dengan standar yang dipersyaratkan.

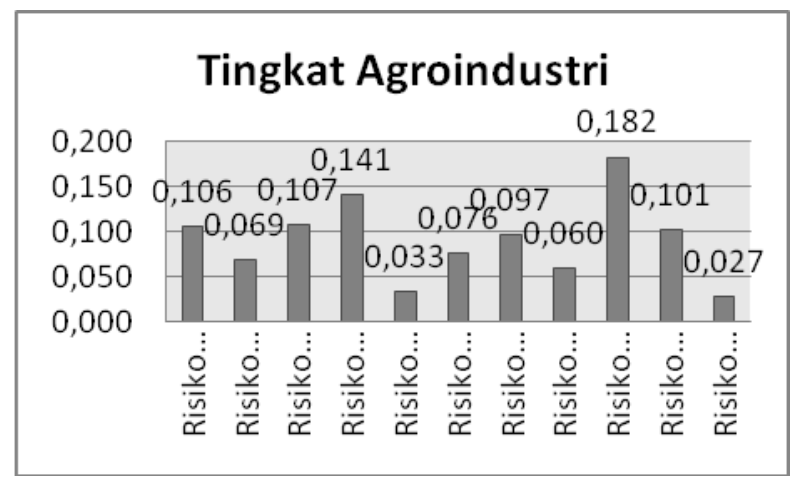

Gambar 11. Histogram perbandingan bobot faktor risiko di tingkat agroindustri

III.6. Analisis risiko tingkat distributor

Faktor risiko yang mempunyai bobot tertinggi dari hasil identifikasi risiko dengan menggunakan fuzzy AHP pada tingkat distributor dalam rantai pasok komoditas jagung adalah risiko harga, risiko pasokan, risiko mutu dan risiko penyimpanan. Penjelasan detail dari perbandingan faktor risiko tingkat distributor hasil analisis dapat dilihat pada Gambar 12.

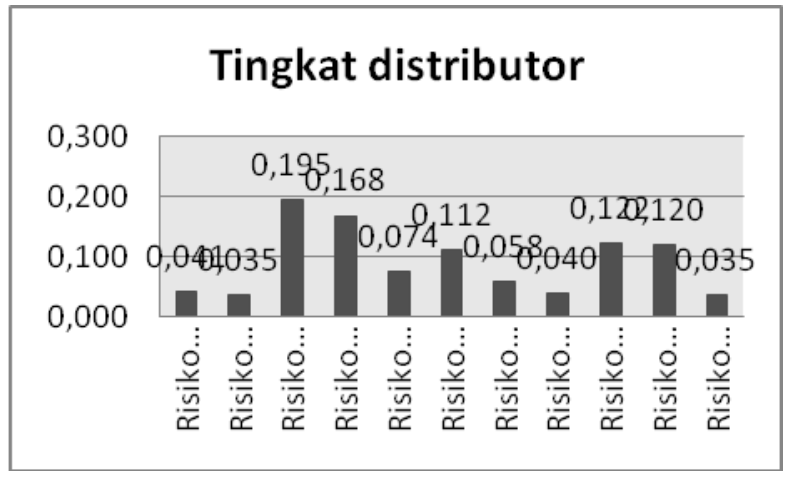

Gambar 12. Histogram perbandingan bobot faktor risiko di tingkat distributor

Hasil evaluasi peubah risiko pada tingkat distributor dalam rantai pasok komoditas jagung menunjukkan bahwa keempat faktor risiko utama yang diperoleh dari hasil evaluasi faktor risiko tidak mendapatkan peubah risiko yang cukup penting untuk diperhatikan dalam analisis risiko rantai pasok, karena semua peubah risiko pada tingkat distributor mempunyai nilai rendah. 
Dari hasil wawancara dengan beberapa pihak distributor komoditas jagung, diperoleh beberapa risiko yang perlu diperhatikan dalam tingkat distributor, yaitu risiko harga karena adanya produk pesaing, risiko peramalan pasokan dan informasi harga pasar, risiko penyimpanan akibat penyusutan produk. Untuk mengatasi hal ini biasanya pihak distributor melakukan kerjasama dengan pelanggan dan prosessor dalam penjualan produk dengan meningkatkan komitmen, serta kepercayaan pada pelanggan.

\section{III.7. Analisis risiko tingkat konsumen}

Dari hasil identifikasi risiko di tingkat konsumen dengan menggunakan fuzzy AHP diperoleh bahwa empat faktor risiko yang mempunyai bobot tertinggi adalah risiko mutu, risiko pasokan, risiko harga dan risiko lingkungan. Nilai-nilai dari keempat faktor risiko tersebut dapat dijelaskan dengan Gambar 13.

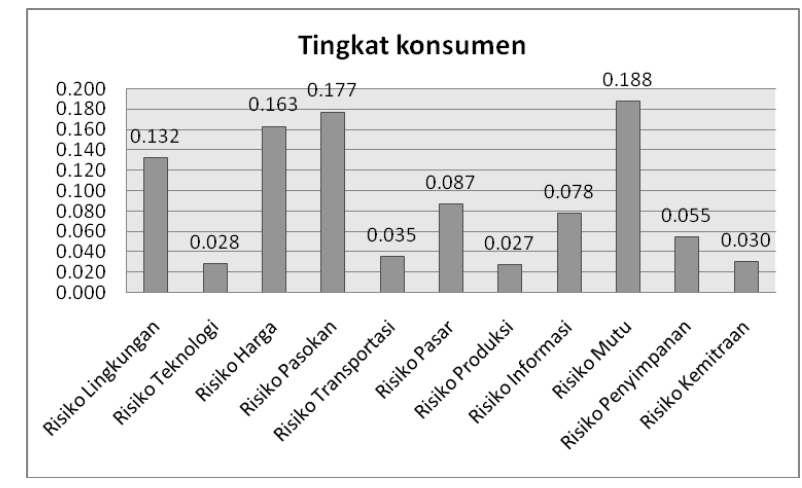

Gambar 13. Histogram perbandingan bobot faktor risiko di tingkat konsumen

Berdasarkan hasil evaluasi risiko terhadap keempat faktor risiko tersebut diperoleh bahwa faktor risiko dengan nilai tertinggi adalah risiko harga yang dipengaruhi oleh adanya fluktuasi harga bahan baku komoditas jagung. Untuk mengatasi risiko tersebut dapat dilakukan kerjasama dalam rantai pasok komoditas jagung, guna menentukan harga kesepakatan bersama yang saling menguntungkan. Adanya fluktuasi harga akan menyulitkan dalam peramalan produksi, penjadwalan dan penentuan harga produk. Dengan adanya kesepakatan harga secara bersama diperoleh suatu kepastian harga dan proses bisnis selanjutnya.

\section{III.8. Analisis risiko rantai pasok}

Dari hasil agregasi risiko rantai pasok terhadap setiap tingkatan rantai pasok komoditas jagung diperoleh empat faktor risiko utama yang perlu diperhatikan dalam manajemen risiko rantai pasok komoditas jagung yaitu risiko mutu, risiko pasokan, risiko harga dan risiko lingkungan. Risiko mutu mempunyai bobot yang paling tinggi dalam manajemen risiko rantai pasok komoditas jagung, karena komoditas jagung saat ini paling banyak digunakan sebagai bahan baku industri pakan dan dalam industri tersebut mempunyai persyaratan mutu yang cukup ketat dalam hal kandungan aflatoksin dan kadar air. Penjelasan detail dari faktor risiko rantai pasok tersebut dapat dijelaskan dengan Gambar 14.

Selain itu, risiko harga juga dipentingkan dalam rantai pasok, karena komoditas jagung mempunyai harga yang cenderung fluktuatif akibat dari ketersediaan jagung 
yang musiman, sehingga pasokannya juga fluktuatif. Di lain pihak, kebutuhan jagung pada industri pakan menuntut adanya ketersediaan jagung kontinu sepanjang tahun baik dalam kuantitas ataupun mutu. Untuk itu, perlu adanya antisipasi terhadap konflik tersebut sehingga diperoleh suatu rantai pasok yang berkesinambungan. Risiko lingkungan juga perlu diperhatikan dalam rantai pasok komoditas jagung, karena adanya ketidakpastian dari isu-isu sosial dan politik yang dapat mempengaruhi kelancaran pasokan, di samping adanya hama dan penyakit pada jagung juga bisa menimbulkan gangguan dalam jaringan rantai pasok.

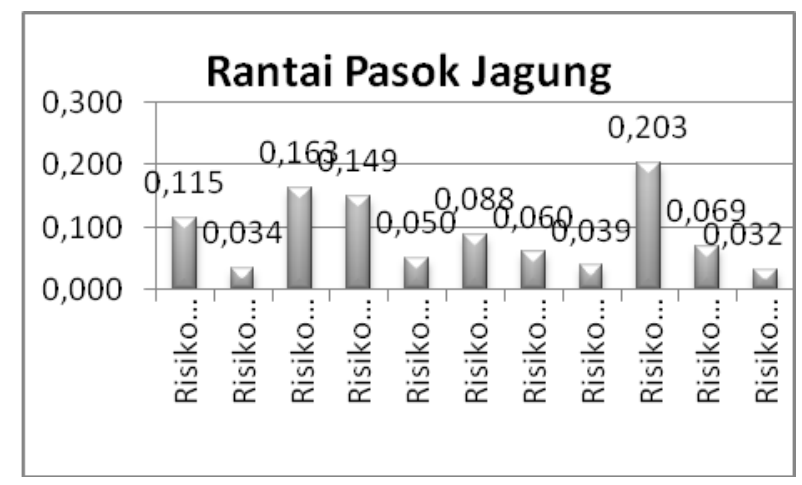

Gambar 14. Histogram perbandingan bobot faktor risiko rantai pasok komoditas jagung

\section{Kesimpulan}

Dalam rantai pasok produk/komoditas jagung petani mempunyai risiko yang paling tinggi jika dibandingkan risiko pada tingkat pedagang pengumpul, risiko agroindustri, risiko distributor dan risiko konsumen. Risiko petani dalam manajemen rantai pasok komoditas jagung adalah risiko rendahnya mutu karena proses pasca panen yang kurang baik sehingga menimbulkan penurunan harga jual dan juga karena kurangnya akses informasi pasar sehingga petani tidak mempunyai posisi tawar yang tinggi.

Dalam manajemen risiko rantai pasok komoditas jagung, risiko kritis yang perlu ditanggulangi adalah risiko rendahnya mutu pasokan bahan baku, risiko fluktuasi harga dan pasokan bahan baku, serta risiko distorsi informasi dalam jaringan rantai pasok. Untuk mengatasi dan mengantisipasi adanya risiko-risiko dalam manajemen rantai pasok komoditas jagung dapat dilakukan dengan cara melakukan kontrak kerjasama antar pihak yang berkepentingan dengan pembagian risiko dan keuntungan yang seimbang antar pelaku rantai pasok.

\section{Daftar Pustaka}

Agiwal S, and H. Mohtadi. 2008. Risk mitigating strategies in the food supply chain. Paper prepared for presentation at the American Agricultural Economics Association Annual Meeting. Orlando, FL.

Arifin B, A. Munir, E.S. Hartati, dan D.J. Rachbini. 2001. Food Security and Markets in Indonesia: State-Private Interaction in Rice Trade. Southeast Asia Council for Food Security and Fair Trade. Kuala Lumpur. 
Arisoy O. 2007. Integrated Decision Making in Global Supply Chains and networks, Disertation of The Graduate Faculty of the School of Engineering, University of Pittsburgh, Pittsburgh.

Austin J.E. 1992. Agroindustrial Project Analysis. John Hopkins University Press. Maryland.

Brown J.E. 1994. Agroindustrial Investment and Operations. World Bank Publications. Wassington.

Hallikas JI., U. Karvonen, VM. Pulkkinen, Virolainen, and M. Tuomine. 2004. Risk management processes in supplier networks, Int. J. of Production Economics, 90, 47-58.

Kasryno F, E. Pasandaran, Suyamto, dan MO. Adnyana 2009. Gambaran Umum Ekonomi Jagung Indonesia. http://balitsereal.litbang. deptan.go.id/ind/bjagung/satu.pdf [10 Januari 2009]

Kersten W, P. Hohrath, and M. Böger. 2007. An Empirical Approach To Supply Chain Risk Management: Development of A Strategic Framework. Proceeding POMS2007 Conference.

Klimov R.A, and Y.A. Merkuryev. 2006. Simulation model for supply chain reliability evaluation. Technological and Economic Development of Economy 14(3): 300311.

Lee TYS. 2008. Supply Chain Risk Management. Int. J. Information and Decision Sciences 1(1): 98-114.

Li J, and S.J. Hong. 2007. Towards a New Model of Supply Chain Risk Management: the Cross-Functional Process Mapping Approach. Int. J. Electronic Customer Relationship Management 1(1):91-107.

Marimin. 2007. Teknik dan Aplikasi Pengambilan Keputusan Kriteria Majemuk. PT. Gramedia Widiasarana. Jakarta.

March JG, and Z. Shapira. 1987. Managerial Perspectives on Risk and Risk Taking. Management Science 33:1404.

Miskiyah dan Widaningrum. 2008. Pengendalian Aflatoksin pada pascapanen jagung melalui penerapan HACCP, J. Standarisasi. 10(1):1-10.

Nagurney A, J.M. Cruz, and J. Dong. 2005. Global Supply Chain Networks and Risk Management: A Multi-Agent Framework, publish in Multiagent-Based Supply Chain Management, B. Chaib-draa and J. P. Muller, Editors, Springer, Berlin, Germany, pp 103-134.

Nepal B, O.P. Yadav, and A. Murat. 2010. A fuzzy-AHP approach to prioritization of CS attributes in target planning for automotive product development. Expert Systems with Applications, doi:10.1016/j.eswa.2010.03.048

Neureuther B.D., and G. Kenyon. 2008. A model for evaluating supply chain risk, POMS $19^{\text {th }}$ Annual Conference, La Jolla, California. 
Santoso I. 2005. Rekayasa model manajemen risiko untuk pengembangan agroindustri buah-buahan secara berkelanjutan, disertasi pada Sekolah Pascasarjana, IPB, Bogor.

Sarasutha I.G.P, Suryawati, dan S.L. Margaretha. 2007. Tata Niaga Jagung, Balai Penelitian Tanaman Serealia, Maros.

Schoenherr T, T.V.M. Rao, and T.P. Harrison. 2008. Assessing supply chain risks with the analytic hierarchy process: Providing decision support for the offshoring decision by a US manufacturing company. J. of Purchasing and Supply Management, doi:10.1016/j.pursup. 2008.01.008.

Suharjito dan Marimin. 2008. Strategi pengembangan agroindustri bioetanol dengan pendekatan logika fuzzy. Proceeding Seminar SNTI. ISSN: 1829-9156.

Vorst, JGAJ van der. 2006. Performance Measurement in Agrifood Supply Chain Networks: An Overview. Quantifying the Agri-Food Supply Chain. C. Ondersteijn, Â. J. Wijnands, R. Huirne, O. van Kooten. Springer Science Business Media. Bab 2:13-24

Wu D, and D.L. Olson. 2008. Supply chain risk, simulation, and vendor selection. Int.J. of Production Economics doi:10.1016/j.ijpe.2008. 02.013.

Wu T, J. Blackhurst, and V. Chidambaram. 2006. A model for inbound supply risk analysis. Computers in Industry 57 (4):350-365.

Xiaohui W, Z. Xiaobing, S. Shiji, and W. Chenf. 2006. Study on risk analysis of supply chain enterprises, Journal of Systems Engineering and Electronics 17(4):781787.

Yeh R.H. and M.H. Hsieh., 2007, Fuzzy assessment of FMEA for a sewage plant. J. of the Chinese Institute of Industrial Engineers, 24, 505-512.

Zubachtirodin, M.S. Pabbage, dan Subandi. 2007. Wilayah Produksi dan Potensi Pengembangan Jagung, Balai Penelitian Tanaman Serealia, Maros 